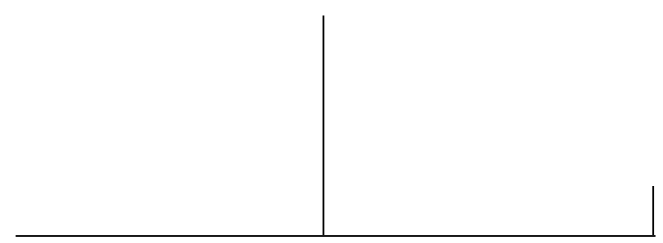

Rev. Latinoam. Psicopat. Fund., São Paulo, v. 15, n. 3, p. 683-703, setembro 2012 (Suplemento)

\title{
Orality Disorders in Melancholia: Acedia as Stagnation*
}

\author{
Ana Cecília Magtaz \\ Manoel Tosta Berlinck
}

In this article valuable contributions by Lasègue, Freud and Abraham are discussed, as they are all indispensible to the understanding of orality disorders in melancholia. Although none of the above authors used the exact term "orality disorders," their understandings of both hysteria and melancholia are important in the debate surrounding the clinical treatment of these difficulties. Sadness is a common denominator for the authors, but contributions on acedia, the "noonday demon" mentioned by Agamben, are also important. Acedia is defined as stagnation, a desperate lack of vigor when faced with a wearying and demanding situation. Those who suffer from chronic acedia feel great inertia and are unable to envision a future. They see their creativity wane away, especially due to the painful isolation caused by what might be called anguished sadness - a denial of sadness through manic action.

Key words: Orality disorders, melancholia, sadness, acedia

* This is a modified version of Magtaz, A.C. \& Berlinck, M.T., "Orality disorders in melancholia: acedia as stagnation", published in Trivium, year II, first semester of 2010, p. 276-289. Translated by Luana Villac. 


\section{Introduction}

The unfolding of the Ph.D. dissertation entitled Orality disorders in melancholia (Magtaz, 2008) is illustrated by distinct moments. Initially, the dissertation has presented the transition from an eating disorder approach to an orality disorder approach. Our intention was to set aside the concern with pathological eating behaviors - in anorexia, bulimia and obesity - in order to understand the modes of functioning of the psyche underlying these symptoms. The psychopathological matter in anorexia, bulimia and obesity is far from being an eating behavior issue. Addressing them as orality disorders, from the perspective of psychoanalysis, opens the possibility of thinking about what is most important in the human experience: the desire, which is constituted in relation to an object. In clinical practice, psychoanalysts hear precious expressions about the oral representations of desire, to be used in the transference: "potty mouth", "loose lips", "mouthy child", "down in the mouth", "put your foot in your mouth", "smart mouth", "big mouth", "to eat your words", "to eat your heart out", "open your mouth and close your eyes", among others.

Following the initial statement, the second moment of the dissertation has defended the idea that orality disorders are symptoms of melancholia, a narcissistic neurosis (Magtaz, 2008). This perspective does not rule out the possibility of there also being orality disorders in other defensive structures, such as in hysteria or perversion. In other words, anorexia, bulimia, obesity and addictions in general are symptomatic expressions that can occur in melancholic dimensions of transference neuroses, psychoses and perversion. The superego being a structural dimension of the psychic apparatus, the shadow of the object can fall upon the ego, regardless of the subject's psychopathological structure. This means that the narcissistic neurosis dynamics are relatively independent of the transference neurosis where, contrary to the former, the conflict takes place between id and ego. 


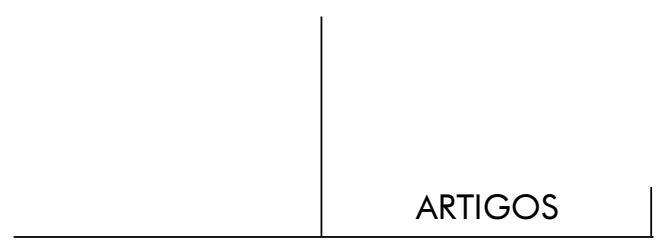

This view is consistent with the contributions of Sandor Radó (1927). Clinician and theorist in psychoanalysis, Radó has brought important contributions to Freud and Abraham's first psychoanalytical findings on melancholia. He states that the depressive process in transference neuroses develops similarly to the melancholic mechanism. That is to say, the neurotic depression is also based on a narcissistic withdrawal from reality, as happens in melancholia: it replaces the external object by psychic instances and aspires to solve the conflict in the psychic scenario, instead of doing it in the outside world, through an activated oral regressive technique.

Lasègue (1816-1883), Freud (1856-1939) and Abraham (1877-1925) understood anorexia/bulimia/obesity as symptoms, rather than specific clinical entities. Furthermore, sadness and its denial by means of manic actions are discussed in their writings. It was necessary to visit the Noonday Demon, the religious acedia, a fascinating experience from the Middle Ages, in order to understand the matter of stagnation - the anguished sadness - present in the orality disorders (Crislip, 2005; Forthomme, 2000).

\section{Charles Lasègue}

The valuable work of Charles Lasègue entitled "On Hysterical Anorexia", published in 1873 , is notable among the authors who have dedicated themselves to the careful observation of psychological dimensions in eating, digestive and appetite disorders.

Lasègue has addressed anorexia nervosa as a sparkling symptom present in the context of hysteria. He sought to focus on the initial phase of the symptoms, the important relationship of the patient with his family - he was certainly the precursor to acknowledging the importance of family dynamics in the persistence of the symptoms - and with the physician.

The present paper is a result of his project to compose a history of hysterical affections by the separate study of each symptomatic group.

To Lasègue, several digestive, appetite and eating disorders can arise in the course of hysteria. The purpose of his article is to present one of the kinds of hysteria of the gastric center. The term anorexia could be replaced by hysterical starvation, which might better represent the visible part of the problem. Accordingly, Lasègue comments that "it follows that we lack words to designate the degrees or varieties of lack of appetite. Here, as in many places, poverty of vocabulary reflects lack of knowledge" (p. 159). 
Lasègue finds, in one extreme, hysterics with no appetite, disgusted by a few to several foods, and in another, some with compelling "demanding appetites". He describes a young lady between fifteen and twenty years old who begins, at first, to feel unwell after eating, right from the start of meals: "Vague feelings of anxiety and gastralgia. Neither she nor the people around her see it as something important, and no durable nuisance seem to come from it" (p. 160). However, the feeling lingers for several days and the young lady comes to the conclusion that the best way to eliminate the discomfort is to decrease food intake. After a while, the discomfort ceases to be a fleeting thing and appears as a refusal to eat that will be experienced for a long period of time:

The stomach pain that is or appears to be the starting point of the accidents especially deserves dwelling upon. It varies in intensity, from a confused feeling of oppression to a kind of stomach cramp followed by weakness, pallor, sweating or chills. (p. 161)

He points out that the painful sensation is not there only as a result of food intake. It persists between meals, sometimes mild, sometimes uncomfortable. The patient begins to fear the pain. Abstaining from food relieves both the pain and the fear of it.

Lasègue emphasizes: "The patient, rather than getting weak and sad, manifests a kind of alacrity unusual to her" (p. 162). And continues further: "Far from muscular power being diminished, this abstinence tends to increase the aptitude for movement" (p. 163).

The family begins to worry about her condition. Gradually, the anorexia becomes the sole subject of concern in conversations. "The more central it becomes, the more the notion of malaise is refined" (p. 164), says Lasègue. And continues: "What dominates in the mental condition of the hysterical patient is, above all, the state of quietude - I might almost say a condition of contentment truly pathological" (p. 165). The patient says that eating causes pain and suffering. Not eating provokes an intense feeling of well-being. At this stage, the doctor has nothing to do to in order to get the patient to look after herself.

Still according to Lasègue, weight loss progresses along with general weakness. The active symptoms decrease while the vital resistance starts to fade. The hysteric is now seen as a sick person and loses the right to come and go. At this point she often fidgets with the people around her and the encircling atmosphere of sorrow and concern. The doctor should then attempt to resume treatment, for the patient, albeit in disguised form, begins to feel a desire to take care of herself and her condition may change.

The relevance of Lasègue's article lies in the point of urgency from which hysterical patients summon the physician's attention: they felt good with the 


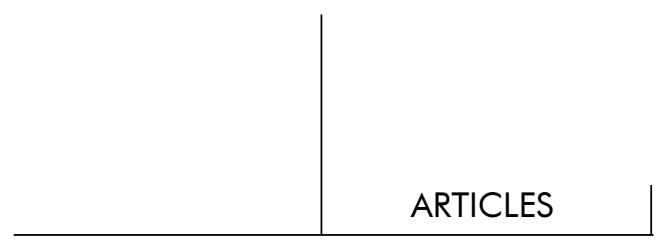

refusal to eat and requested to be viewed through the manifestation of an "aptitude for movement" instead of the expected apathy. The very urgency that is found in what could be called manic action and which is manifested in the anorexic wandering, the bulimic frenzy, the binge eating of the obese and in addictions in general. It is important to highlight, as Lasègue observes, that the patient will only accept help when the manic action fades and gives way to what might be called a sadness-sign.

Lasègue article also provides an insight into the illusion of narcissistic gratification (cf. Bleichmar, 1985, p. 131). It is possible to recognize, in the hysterical anorexia described by him, a narcissistic retreat manifested by the manic action (illusory form of narcissistic gratification - feeling of well being described by patients) before suffering - malaise - dislocated to food, appetite and digestion. What characterizes the narcissistic pain? Before we attempt to answer this question, we shall look at Freud's and Abraham's contributions to the understanding of the narcissistic retreat through the means of hysteria and melancholia.

\section{Sigmund Freud}

In Freud's early works, anorexia and repeated vomiting are presented as symptoms of both melancholia and hysteria.

In his Draft G. Melancholia (1950[1892-1899]) Freud establishes an analogy between anorexic symptoms and melancholia:

There are striking connections between melancholia and (sexual) anesthesia. This is borne out:

1) By the finding that in so many melancholics there has been a long previous history of anesthesia, 2) by the observation that everything that provokes anesthesia encourages the development of melancholia, 3) by the existence of a type of woman, very needy psychically, in whom longing easily changes into melancholia".

(b) The nutritional neurosis parallel to melancholia is anorexia. The famous anorexia nervosa of young girls seems to me (on careful observation) to be a melancholia where sexuality is underdeveloped. The patient asserts she has not eaten simply because she had no appetite and for no other reason. Loss of appetite - in sexual terms - loss of libido. (p. 282-83)

These important observations about anesthesia are helpful to think over the problem of insensitivity present in oral disorders, an insensitivity that appears in symptoms of anorexia as a refusal to feel painful stimuli. In obesity, this

Rev. Latinoam. Psicopat. Fund., São Paulo, v. 15, n. 3, p. 683-703, setembro 2012 (Suppl.) 
insensitivity is linked to the layer of fat that coats and deadens the flesh. More than a "loss of libido," as Freud points out, it would be a stagnation of libido, which would generate insensitivity on psychic and corporeal levels. Freud postulates anorexia nervosa as a form of hysterical anesthesia, a way to silence the pain and produce stagnation.

What constitutes the sadness-sign indicated by Lasègue and recognized by Freud in his hysterical patients? How does it manifest in clinical practice when dealing with orality disorders?

Freud draws attention to the necessity of linking anorexic/vomiting symptoms to the oral phase of sexual life in the psychological work of hysteria. That allows us to think that the hysteric lives stuck in the past, the reminiscences of a past that leave her fixated, bound by means of a conversion symptom. The hysterical patient "feeds" herself from this past hoping to find in it a chance to redo an illusion (dissolved like a mirage that disappears in the desert), something that would ensure an illusory moment of plenitude before the loss of the object - an illusion of narcissistic gratification.

Freud's proposal in "Mourning and Melancholia" (1917), is to clarify the nature of psychopathological melancholy. To do so, he describes the psychic work of mourning over the loss of the loved object and on this basis reflects on the psychological work of melancholia.

The work carried out by mourning respects reality-testing, revealing that the loved object no longer exists and requiring the libido to withdraw from its relations maintained with this object. However, this demand from reality is not answered promptly, taking time and requiring a huge expenditure of energy. The ego, losing interest in the outside world, is absorbed by an arduous inner process of working through the loss, whose ultimate goal is to let go of the object (cf. Rosenberg, 2003, p. 119-156). When the work of mourning is completed, the ego becomes free and uninhibited again. Thus he describes:

They are carried out bit by bit at great expense of time and cathectic energy, and in the meantime the existence of the lost object is psychically prolonged. Each single one of the memories and expectations in which the libido is bound to the object is brought up and hypercathected, and the detachment of the libido is accomplished in respect of it. (p. 104-5)

When comparing mourning to melancholia Freud points out that:

In melancholia the unknown loss will result in a similar internal work and will therefore be responsible for the melancholic inhibition. The inhibition of the melancholic seems puzzling because we cannot see what it is that absorbs him so entirely. The melancholic displays something else besides which is lacking in mourning: an extraordinary diminution in his self-regard, an impoverishment of his ego on a grand scale. (p. 105)

Rev. Latinoam. Psicopat. Fund., São Paulo, v. 15, n. 3, p. 683-703, setembro 2012 (Suppl.) 


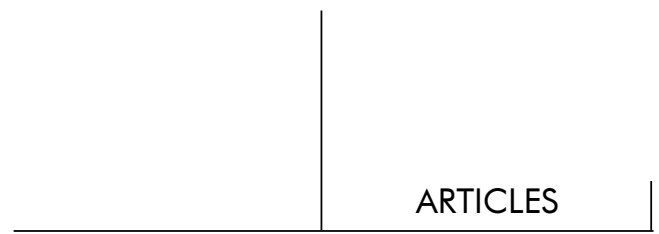

Hence, internal work that consumes and devours the ego takes place in melancholia, which is expressed by a delusion of unworthiness, punctuated by self-depreciation: "He also seems to us justified in other self-accusations; it is merely that he has a keener eye for the truth than other people who are not melancholic (p. 106).

This passage is valuable to the clinical practice in melancholia for, indeed, the patient suffers from what might be called an excess of reality when it comes to the loss of his ego (he violently loses the illusion of narcissistic gratification). This excess of reality refers, in our view, to the "open wound drawing to itself cathectic energies from all directions and emptying the ego until it is totally impoverished" (p. 111). In this case, the reality principle stops operating and the patient is unable to produce representations.

Freud seeks to clarify the contradiction between the loss of the object in grief and the loss that occurred in the ego, characteristic of melancholia:

If one listens patiently to a melancholic many and various self-accusations, one cannot in the end avoid the impression that often, the most violent of them are hardly at all applicable to the patient himself, but that with insignificant modifications they do fit someone else, someone whom the patient loves or has loved or should love.(...) So we find the key to the clinical picture: we perceive that the self-reproaches are reproaches against a loved object which have been shifted away from it on to the patient's own ego. (p. 107).

Freud reconstructs the melancholic process as follows:

An object-choice, an attachment of the libido to a particular person, has at one time existed; then, owing to a real slight or disappointment coming from this loved person, the object-relationship was shattered. The result was not the normal one of a withdrawal of the libido from this object and a displacement of it to a new one, but something different, for whose coming-about various conditions seem to be necessary. The object-cathexis proved to have little power of resistance and was brought to an end. But the free libido was not displaced on to another object; it was withdrawn into the ego. There, however, it was not employed in any unspecified way, but served to establish an identification of the ego with the abandoned object. Thus the shadow of the object fell upon the ego. (p. 108)

Thereafter the ego undergoes a cleavage and a special agency, the shadow, will judge the latter as though it were the forsaken object: "

1. Later on, in The Ego and the Id, Freud (1923) will expound the superego's sadism in relation to the ego in melancholia. See the works of Marta Rezende. Superego, 2002 and Marta Gerez Ambertin. Imperativos do supereu (Superego imperatives), 2006. 
the ego and the loved person (became) a cleavage between the critical activity of the ego and the ego as altered by identification" (p. 108).

According to Freud, the disposition to melancholia is directly related to the narcissistic type of object-choice. There is a regression of the erotic cathexis to the oral libidinal stage, a preliminary stage of object-choice.

Identifications with the object are by no means rare in the transferences neuroses either; indeed they are a well-known mechanism of symptom-formation, especially in hysteria. The difference, however, between narcissistic and hysterical identification may be seen in this: that, whereas, in the former the object-cathexis is abandoned, in the latter it persists and manifests its influence. (p. 109)

Freud hints here at the conflict between ego and superego in the transference neuroses. Since the superego is a topical dimension of the psychic apparatus, the shadow of the object can befall the ego, regardless of the subject's psychopathological structure. This means that narcissistic neurosis has dynamics relatively independent from the transference neurosis, where, unlike the former, the conflict takes place between id and ego.

Freud (1917) also establishes that the most notable feature of melancholy, one that leaves plenty of room for questions and opens to a field of research, is its tendency to turn into its opposite, i.e., mania.

Mania, in his view, is a release of a quantum of energy that had previously been consumed in the ambivalent relationship with the object incorporated to the ego. A disposition for all forms of releasing actions would be present here, as well as a triumph over sadness and melancholic inhibition, a relish taken in movement and action. What has been dominated by the ego, and over which it is triumphing, remains hidden for him. ${ }^{2}$

What remains hidden from the ego in mania? What does the manic action ensure? What is its relationship with the compulsion of addicts? We saw from Freud, though briefly, what characterizes the work of mourning and melancholia. Would there be any work of mania? What kind of psychic work is characteristic of mania? What is its relationship to the ideal?

2. Berlinck, M. T. (2003) develops this same argument in "Mania de festas" (Parties Mania). Pulsional Revista de Psicanálise, year 16, v. 169, p. 3-8. 


\section{ARTICLES}

Abraham

Abraham's first works, entitled "The first pre-genital stage of the libido" (1916) and "Short study of the development of the libido, viewed in the light of mental disorders" (1924a), are important, for they present valuable contributions about clinical practice for orality disorders.

Having Freud's "Three essays on the theory of sexuality" as a starting point, "The first pre-genital stage of the libido" deepens the conception about the psychopathology of the most primitive pre-genital organization of the libido: the oral stage.

Freud has called pre-genital the stages of development of the libido previous to the setting in of the primacy of the genital zone. They are stages that precede that of later sexuality and are typical of childhood experiences. In pathological cases, such processes become active and noticeable for their prevalence in adult life.

Abraham discerns in Freud's writing the existence of two pre-genital organizations. The earliest is the oral stage, which may also be called the cannibalistic stage. In this stage, sexual activity is not yet separated from the taking of nourishment. The second pre-genital phase is the sadistic-anal organization, where the duality of sexual life must be termed active and passive.

Abraham presents several fragments of clinical cases demonstrating that the instinctual life of the child persists in adulthood and that the libido of any such person presents a psychopathological picture that appear to correspond to the oral stage. These are the psychic states of depression.

"Many neurotics suffer from abnormal feelings of hunger. Women in particular are affected with this symptom." (Abraham, 1916, p. 64). He calls this urge "neurotic hunger", which does not correspond to ordinary hunger, and comments on its particularity:

Certain characteristics of this neurotic hunger are to be noted, namely, that it has no relation to whether the stomach is full or empty, that it comes on at irregular intervals, and that it sets in like an attack with accompaniments of a harassing nature which do not belong to the normal need for nourishment, the most important of which are feelings of anxiety. (p. 64)

The patients often complain about "attacks of ravenous hunger" (p. 64). They show resistance when psychoanalysis discloses the connections of their neurotic ravenous hunger with repressed libido. Abraham draws attention to the great frequency of these attacks in frigid women. Repressed libidinal impulses can be well-masked by a feeling of hunger, for hunger can be admitted to oneself and to others, even when it is excessive.

Rev. Latinoam. Psicopat. Fund., São Paulo, v. 15, n. 3, p. 683-703, setembro 2012 (Suppl.) 
Abraham presents various clinical cases displaying the desire of indulging in sucking activities, in some cases, and a craving for taking solid food too frequently in others. In the latter, orality is not disconnected from nourishment.

To Abraham, adult thumb-suckers, although addicted to this auto-erotic activity, are in a more advanced stage of libidinal development than those fixated on the pleasure of taking food. Their libido has achieved some independence from nutriment, and the pleasure is located in the auto-erotic body. The mouth has not lost its place as an erogenous zone. In his words:

The thumb-sucking of adults which appears so strange to us is more explicable when we remember that in normal adults the moth has not quite lost its role of an erotogenic zone. We look upon kissing as a thoroughly normal expression of the libido, although it is true that the erotogenic zone in this case serves the purpose of object-love. The kiss does not claim the significance of a final sexual aim, but only represents a preparatory act. And yet here, too, the boundaries are ill-defined; certain forms of kisses can constitute the essential aim of the person's sexual desire. (p. 68)

He presents the case of a young man who showed great inhibition in speaking, and who would at all times perform a kind of oral masturbation: $\mathrm{He}$ made continual sucking movements, used his tongue to make tickling movements against his palate and sucked in his cheeks. His mouth was endlessly requested as an erogenous zone and could not fulfill other oral functions of non-sexual nature: the orality of language and writing.

Abraham also discusses the matter of disposition and "neurotic depression of spirits" (p. 72). He states that "the neurotic person's auto-erotic gratification has two uses: it prevents a depression of spirits when it is threatened and removes it when it is there" (p. 72). He addresses neurotics who use pleasurable oral stimulation to dispel their depression and reports the following fragment of a case study:

The case of a young cyclothymic female patient whom I had under observation is particularly instructive. She was scarcely able to get mental contact with other people at all, and had tended to withdraw from them and yield entirely to her auto-erotic inclinations. When she became depressed she used to employ various means to relieve her condition, of which the chief one interests us here. This was to buy some food. Even while she was eating it she would feel her spirits rise. Another method which acted beneficially on her frame of mind was characteristic of her auto-erotic tendencies. She used to ride in a train for hours and obtain from this a very marked pleasure in movement. (p. 73)

Abraham's observation meets the "aptitude for movement" observed by Lasègue in his hysterical patients: pleasure and sense of well-being - as an illusion 
of narcissistic gratification - to assuage anguish and sorrow. There would be a gradation in this aptitude for movement that may go from something rhythmic and continuous, lulling-like, to rapid and frenetic movements, such as a manic action that prevents thinking (e.g., walking excessively and non-stop eating to vomit).

Amongst the most important expressions of depressive mental disorders are two symptoms that present a straight connection with orality: the refusal to take food and the fear of dying of starvation. In this case, eating takes the place of loving; the melancholic loses his ability to love while, at the same time, is afraid of loving to death. The nature of the forces responsible for the stagnation characteristic of melancholia is thus revealed.

A deep understanding of this neurotic manifestation led Abraham to conclude that in these patients the libido has regressed to the most primitive stage of its development: the oral stage. The more the genital zone retires into the background as a source of pleasure, the more people turn back to oral and anal eroticism.

In melancholic depression, the libido seems to regress to its most primitive stage of development; unconsciously the melancholic directs upon the love-object the wish to incorporate it, devour it to demolish it. "The unconscious wish of the melancholic is to destroy his love-object by eating it up" (p. 78).

If we assume that the deepest repressed wishes of the melancholic are of a cannibalistic nature, that his 'sins' in their essence refer to a forbidden, even detested, act of eating, then we understand the great frequency with which he refuses to take food. He behaves as though complete abstention from food could alone keep him from carrying out his repressed impulses. At the same time he threatens himself with that punishment which is alone fitting for his unconscious cannibalistic impulses - death by starvation. (p. 79)

To Abraham, cannibalistic fantasies exist both in melancholia and in transference neuroses. The introjection of the love-object corresponds to an incorporation of it, following the regression of the libido to the oral cannibalistic level. When introjecting the lost object, the melancholic is actually calling it to life by installing it within his own ego. Melancholia is an archaic form of mourning, and the work of mourning in transference neuroses takes a mental form which is also archaic: absorbing the object within the ego. The melancholic's process of introjection is centered around a serious conflict of ambivalent feelings, from which he can only escape by turning unto himself the hostility felt towards the object.

In "Short study of the development of the libido, viewed in the light of mental disorders" (1924) Abraham remarks that, unconsciously, the loss of an object is seen as an anal process (expelling) and its introjection as an oral process 
(devouring). In face of the loss or even the threat of losing the love-object, a violent expulsion and an attempt to reincorporate it takes place in melancholia.

Melancholic patients show in dreams, fantasies and symptoms, oral-sadistic tendencies. These tendencies, in most cases, are a source of intense suffering, especially when hate is turned against the subject's ego as self-punishment.

Abraham makes a differentiation within the oral stage of the libido. On the primary level, the libido of the infant is attached to the act of sucking. This is an act of incorporation, but does not eliminate the existence of the object. The child is not able to distinguish between his own ego and the external object. "There is still no differentiation made between the sucking child and the suckling breast". Moreover, the child has neither feelings of hatred nor of love, its psyche is free from all manifestations of ambivalence.

At the secondary level of the oral phase, named by Abraham as oral cannibalistic, it is possible to observe a transition from the act of sucking to the act of biting, where the latter represent sadistic impulses. At this stage, the ego incorporates the object in itself and, in doing so, destroys it. During this stage, the ambivalent attitude of the ego with its object begins to develop and a conflict ensues. Abraham observes that:

All of my psychoanalytic observations up until now lead me to the conclusion that the melancholic is trying to escape from his oral-sadisticimpulses. Beneath these impulses, whose manifestations color the clinical picture, there lurks the desire for a pleasurable, sucking activity. (p. 111)

After the loss of his object, the melancholic regresses to a libidinal level populated by ambivalent primitive feelings; hence, the destruction of the object by devouring it, when it does not meet the insatiable demands of (oral) gratification. "It is only gradually that the ambivalence of conflict assumes a milder aspect, and that the libido consequently adopts a less violent attitude towards its object" (p. 112-91).

Abraham noted accurately that the melancholic has a sense of superiority in his interpersonal relationships derived from the affective ambivalence, treating with contempt and arrogance (hate) those who question his rigid and critical way of thinking. In addition, the melancholic questions the psychiatric approach which believes they suffer from "delusions of inferiority".

Indeed, everything indicates that they are delusions of superiority, especially since the melancholic recognize himself as the greatest sinner in the world or the most miserable creature alive. The superiority in this case is expressed by a radical negativity.

Thus, melancholia presents a picture in which there stands in immediate juxtaposition yet absolutely opposed to one another self-love and self-hatred, an

Rev. Latinoam. Psicopat. Fund., São Paulo, v. 15, n. 3, p. 683-703, setembro 2012 (Suppl.) 


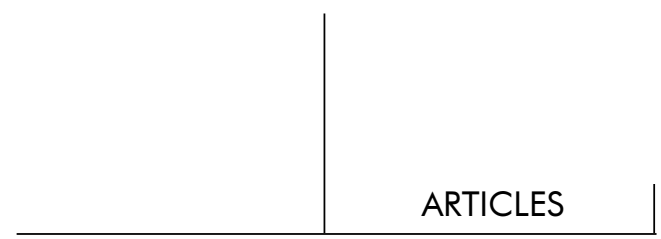

overestimation of the ego and an underestimation of it, the manifestations, that is of a positive and a negative narcissism. (p. 116)

Abraham explains that the psychogenesis of melancholia is linked, among other factors, to "disappointments in love" (p. 117) that occurred in the early stages of the patient's life, as had been previously stated by Margarete Hilferding (1991). This primary love disappointment, which can be called loss of the illusion of narcissistic gratification, when relived in later life, can cause melancholic depression. ${ }^{3}$ More precisely, when "the occurrence of the first important disappointment in life happens before the Oedipus whishes have been overcome" (p. 119).

Abraham's ideas expressed here do not refer only to the psychogenesis of melancholia. They refer, in our view, also to the constitution of the ego-ideal, heir to the narcissism, which is built upon the process named by him as introjection ${ }^{4}$ of the love-objects. It is possible to think that, in order for the oedipal wishes to be overcome, dissolved, it is important to have a positive loss of love driving the ego to invest in other objects, to build new relationships. The negative loss of love could boost the ego towards nothingness, to the erasure of life through devastation.

Abraham, quoting Stärcke, ${ }^{5}$ says that the withdrawal of the mother's breast can be experienced as a "primal castration" (cf. also Hassoun, 2002). The melancholic would be fixated on revenge, castrating the very people who so early in life provoked in him an immense feeling of loss of self. He summarizes the process as follows:

When a melancholic person suffers an unbearable disappointment from their love-object, they tend to expel the object as though it were feces and to destroy it. They thereupon accomplish the act of introjecting and devouring it - an act which is a specific melancholic form of narcissistic identification. Their sadistic thirst for vengeance now finds its satisfaction in tormenting the ego - an activity which is in part pleasurable. We have reason to suppose that that period of selftorment lasts until lapse of time and the gradual appeasement of sadistic desires

3. Berlinck, M. T. "Bases do amor materno, fundamentos da melancolia" (Bases of maternal love, the foundation of melancholy). $6^{\circ}$ North Northeast Psychology Congress, Belém, Pará, May 2009.

4. From the considerations of Nicolas Abraham and Maria Torok (1995) in A casca e o núcleo (The Shell and the Core). São Paulo: Escuta regarding the introjection process and fantasies of incorporation, we believe it would be more accurate to use here the term "incorporation" instead of "introjection". But we have chosen to keep the terminology used by Abraham.

5. The Castration Complex, 1921.

Rev. Latinoam. Psicopat. Fund., São Paulo, v. 15, n. 3, p. 683-703, setembro 2012 (Suppl.) 
have removed the love-object from the danger of being destroyed. When this has happened the object can, as it were, come out of its hiding-place in the ego. The melancholic can restore it to its place in the outer world. (p. 124)

He accents, brilliantly, that the melancholic regards such liberation from his restored object as, once more, an "act of evacuation" (mental) and that "during the course of an attack of melancholia the love-object goes through a process of psychological metabolism within the patient" (p. 124).

This process of (mental) metabolism seems particularly interesting as we can relate it to both the negative loss of love and the positive loss of love aforementioned. There would be in all subjects an illusion of ownership of the object that must be undone and worked through throughout life - passage of the ideal ego to the ego-ideal. Undoing this illusion may or may not be positive for the subject. In some cases, the inability to achieve and sustain a complete love as well as an unrelenting hatred could cause an extreme feeling of helplessness as a result of being prevented from owning the object.

In addressing the problem of mania, fundamental to the clinical work in orality disorders, mania seems to be an effect of the evacuation of the object and, thus, a release of the ego. Abraham draws attention to the "gobbling mania" (p. 131): the patient who devours everything that comes his way without discrimination. He relentlessly devours and evacuates simultaneously everything that is voraciously absorbed. There would not be any possibility of mental digestion in mania: it is pure act, without thinking.

\section{Considerations on sadness}

Berlinck (2005) works on the assumption that:

Each manifestation of psychopathology - conversion hysteria, anxiety hysteria, perversion, obsessional neurosis, melancholia, schizophrenia, paranoia - takes possession of space in a peculiar way, revealing a structured dynamic, i.e., a specific landscape dwelling in space (p. 182).

In melancholia, the intrapsychic landscape is organized on a vertical axis. Between the ideal (the heights) and its failure (the abyss) the subject moves ceaselessly, without leaving the verticality, a back-and-forth movement between everything and nothing.

What form would horizontality take? Would there be an intersection between verticality and horizontality? Where is the point of intersection? What actually unites them? 
The point of intersection between verticality and horizontality is the affection called sadness.

Antônio Vieira (1679) believes that sadness has two causes: a positive one, which can be understood, and a negative one, which is incomprehensible. The remedy for sadness would be the possibility of understanding that stems from a fundamental question, "whither thou goest; quo vadis?" In his words:

A man that asks himself, whither thou goest, quo vadis; and sees that along with the steps of time he shall never stop, he shall always walk towards his grave; either leaves behind his back, either shovels under his feet all that sadden those who do not consider it. In the grave, to where we head to, what later will be buried is the body itself and what soon remains buried is all that can cause sorrow in this world. (p. 547)

It is possible to think from the Vieiras's words, that the remedy for sadness is the possibility of displacement on the horizontal axis. The remedy for the sadness that immobilizes, is moving toward a destination and acknowledging this feeling (passage of the ideal ego to the ego-ideal). Perhaps the biggest problem of sadness is never having recognized it as such.

Another writing that can contribute to thinking of the melancholia's vertical axis is Agamben's text entitled "O demônio do meio dia" (The noonday demon) (2007a), which addresses the important matter of acedia.

According to Agamben, in the Middle Ages the priests baptized death that instilled in the soul with the names: acedia, tristitia, taedium vital and desidia. "What afflicts the slothful", Agamben writes, "is not therefore the awareness of an evil, but on the contrary, the contemplation of the greatest of the goods: acedia is precisely the vertiginous and frightened withdrawal (recessus) when faced with the task implied by the man before God" (p. 28).

The slothful does not cease to desire the inaccessible object, the ideal. For not being able to reach it, in the heights, he often immobilizes himself in anguished sadness that leads him towards the vice of wild action or inaction.

Modern psychology, according to Agamben (2007a), has despised and misread the word acedia by turning it into a sin against the capitalist work ethic, calling it laziness. Acedia means numbness, desperate lack of vigor when faced with a wearying and demanding situation. In other words, it is stagnation itself. When faced with difficulties, the subject is swallowed and dominated by sleep and, some time later, is awaked by a feeling of depravation and hunger that demands to be urgently attended to. It is a languor seizing the body along with a "rabid hunger for food" (p. 23). Agamben also draws attention to an important ambiguity present in acedia: often the acidious, though languid, lives an "impossibility of stopping" and "constant availability of distraction". Acedia is, 
hence, associated with an anguished sadness that, while not being recognized as such, leaves the soul restless and affects the body in all of its creative dimension (Forthomme, 2000; Crislip, 2005).

The vertical relationship with the ideal denotes a realization of the existence of a point to be reached; however, there is no possible way towards it. Reaching the ideal is to happen in a magical and omnipotent way.

Remarking upon "Mourning and melancholia", Agamben (2007b), notes that Freud does not understand and feels embarrassed before the following observation: "although mourning follows a loss that has really occurred, in melancholia not only it is unclear what object has been lost, it is uncertain that one can speak of a loss at all" (p. 44).

For Agamben, melancholia presents "an intention to mourn" (p. 44) that precedes the actual loss of the object. He draws an analogy with religious acedia, for it expresses a "withdrawal from a good that had not yet been lost". (p. 44). Melancholia thus, simulates a loss. "Melancholy would be not so much the regressive reaction to the loss of the love object as the imaginative capacity to make an object appears as if lost" (p. 45).

According to him, the melancholic produces an illusion of ownership of the object when referring to its loss. The characteristic ambivalence of melancholia can be understood by making a parallel with the fetishist Verleugnung: "The object is neither appropriated nor lost, but both possessed and lost at the same time" (p. 46). Thus, the object of the melancholic is at once incorporated and lost, affirmed and denied. The triumph of the object happens through suppression; "however, it is precisely in the gesture that abolishes that the melancholic demonstrates his or her extreme fidelity to the object" (p. 46).

From this perspective it is possible to formulate the existence of a melancholic defense mechanism that could be called negative illusion, related to the idea of that which can only be possessed if it is lost forever. We are reminded of Freud's and Abraham's oral cannibalistic phase in the evolution of the libido, in which the melancholic self appropriates the negative when it incorporates the object by devouring it; on one end, it destroys the object, on the other end, it gives life to it. "If the external world is in fact narcissistically denied to the melancholic as an object of love, the phantasm yet receives from this negation a reality principle and emerges from the mute interior crypt in order to enter a new and fundamental dimension" (Agamben, 2007c, p. 53).

We understand illusion as a phenomenon characteristics of both narcissistic and transference neuroses. The regression to the oral cannibalistic phase is the very base of melancholia, and thus the negative illusion.

We chose the term negative illusion rather than negative hallucination mainly because the ego feeds on illusions and negative illusions related to ideals. Illusion, 


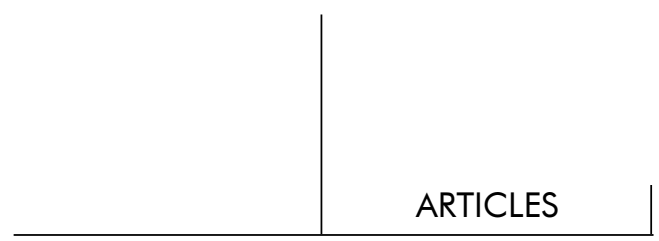

unlike negative hallucination, has a linking value and allows for "playing" with reality; what to say about negative illusion? Negative illusion also has a linking value since it implies the denial of reality while giving the ego a magnificent power: it has nothing to lose, since it has already lost everything. Therein the desire present in negative illusion is revealed: the desire of not being deceived again.

It is possible to see that the negative illusion, when denying reality, works to allow the emergence of the illusion of the ideal.

These ideas are very important to understand what characterizes the excess of reality in melancholy that needs to be pacified, often by a wild - manic action. It allows us to say that in melancholia, there can be a failure in the formation of the protective shield against external and internal stimuli. The intense sensitivity of the melancholic, an edgy sensitivity as we see it, turns into its opposite: insensitivity as a form of protection. In mania, the action works as a protective shield against stimuli that are unbearable to the ego, since the ego is confounded with perception, like an open wound.

Under these conditions, how is one to think of the recognized intelligence and creativity of the melancholic?

\section{Bibliography}

Abraham, K. (1916). O primeiro estágio pré-genital da libido. In: Teoria psicanalítica da libido. Rio de Janeiro: Imago, 1970. p. 51-80.

Aвraham, K. (1924). Breve estudo do desenvolvimento da libido visto à luz das perturbações mentais. In: Teoria psicanalítica da libido. Rio de Janeiro: Imago, 1970. p. 81-160.

Abraham, K. (1915). Carta de K. Abraham a S. Freud (31-3-1915). Imago-Revista de Psicoanálisis, psiquiatria y psicologia, Buenos Aires, n. 13, p. 7-9, 1990.

Abraham, N.; Torok, M. A casca e o núcleo. São Paulo: Escuta, 1995.

Agamben, G. O demônio meridiano. In: Estâncias. A palavra e o fantasma na cultura ocidental. Belo Horizonte: Editora UFMG, 2007a, p. 21-32.

Agamben, G. O objeto perdido. In: Estâncias. A palavra e o fantasma na cultura ocidental. Belo Horizonte: Editora UFMG, 2007b, p. 43-47.

Agamben, G. Os fantasmas de eros. In: Estâncias. A palavra e o fantasma na cultura ocidental. Belo Horizonte: Editora UFMG, 2007c, p. 48-56.

Ambertin, M. G. Imperativos do supereu. São Paulo: Escuta, 2006. 
Berlinck, M. T. Mania de festas. Pulsional Revista de Psicanálise, ano 16, n. 169, p. 3-8, 2003.

Berlinck, M. T. Paisagem e existência. Revista Psicologia Clínica, PUC-RJ, v. 17, n.1, p. 177-190, 2005.

Berlinck, M. T. As bases do amor materno, fundamento da melancolia. $6^{\circ}$ Congresso Norte Nordeste de Psicologia, Belém, Pará, maio de 2009.

Bleichmar, H. O narcisismo. Estudo sobre a enunciação e a gramática inconsciente. Porto Alegre: Artes Médicas, 1985.

Cardoso, M. R. Superego. São Paulo: Escuta, 2002.

CRISLIP, A. The Sin of Sloth or the Illness of the Demons? The Demon of Acedia in Early Christian Monasticism. Harvard Theological Review, v. 98, n. 2, p. 143-69, 2005.

Forthomme, B. De l'acédie monastique à l'anxio-dépression. Histoire philosophique de la transformation d'une vice en pathologie. Paris: Institut D'Édition SanofiSynthélabo, 2000.

Freud, S. (1950[1892-1899]). Extratos de documentos dirigidos a Fliess. In: Edição Standard Brasileira das Obras Psicológicas Completas de Sigmund Freud. Rio de Janeiro: Imago, 1969. v. I, p. 243-380.

FREUd, S. (1893-1895). Estudos sobre a histeria. In: Edição Standard Brasileira das Obras Psicológicas Completas de Sigmund Freud. Rio de Janeiro: Imago, 1969. v. II. p. 13-318.

Freud, S. (1917). Luto e melancolia. In: Escritos sobre a psicologia do inconsciente, volume II: 1915-1920/ Sigmund Freud. Rio de Janeiro: Imago, 2006. p. 103-122.

Freud, S. (1923). O Ego e o Id. In: Edição Standard Brasileira das Obras Psicológicas Completas de Sigmund Freud. Rio de Janeiro, Imago, 1969. v. XIX, p. 13-80.

Hassoun, J. A crueldade melancólica. Rio de Janeiro: Civilização Brasileira, 2002.

Hilferding, M.; Pinheiro, T.; Vianna, H. B. As bases do amor materno. São Paulo: Escuta, 1991.

Lasegue, C. (1973). Da anorexia histérica. Revista Latinoamericana de Psicopatologia Fundamental, São Paulo, v. I, n. 3, p. 158-71, set.1998.

Magtaz, A. C. Distúrbios da oralidade na melancolia. 2008. Tese (Doutorado em Psicologia Clínica). Pontifícia Universidade Católica de São Paulo, 2008.

RAdO, S. (1927). El problema de la melancolia. In: GARMA, A.; RASCOvSKY, L. Psicoanálisis de la melancolia. Buenos Aires: El Ateneo, 1948. p. 251-70.

Rosenberg, B. Masoquismo mortífero e masoquismo guardião da vida. São Paulo: 


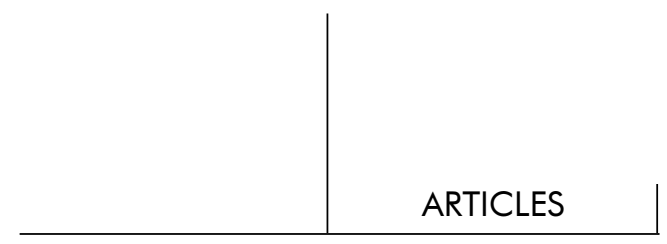

Escuta, 2003.

VieIRA, Padre Antônio (1679). Sermão da quarta dominga depois da Páscoa. Revista Latinoamericana de Psicopatologia Fundamental, São Paulo, v. IX, n. 3, p. 538-64, set.2006.

\begin{abstract}
s
(Distúrbios da oralidade na melancolia: acidia como estagnação)

Este trabalho apresenta as valiosas contribuições de Lasègue, Freud e Abraham, indispensáveis para a compreensão dos distúrbios da oralidade na melancolia. Apesar desses autores não utilizarem a terminologia “distúrbios da oralidade”, sua compreensão tanto da histeria como da melancolia possibilita problematizar uma clínica desses distúrbios. A tristeza é um denominador comum entre esses autores. Juntam-se a eles as contribuições sobre a acídia, o "demônio meridiano", referidas por Agamben. Acídia significa estagnação, desesperada falta de ânimo diante de uma situação trabalhosa e desgastante. $O$ acidioso, aquele que se encontra crônico em sua inércia e incapaz de dimensionar o futuro, apresenta uma estagnação da criatividade revelada por um doloroso isolamento provocado pelo que pode ser chamado de angustiada tristeza - negação da tristeza pela via da ação maníaca.

Palavras-chave: Distúrbios da oralidade, melancolia, tristeza, acídia

(Troubles de l'oralité dans la mélancolie: l'acédie comme stagnation)

Cet article présente les précieuses contributions de Lasègue, Freud et Abraham, indispensable à la compréhension des troubles de l'oralité dans la mélancolie. Bien que ces auteurs n'ont pas utilisé le terme «troubles de l'oralité», leur compréhension de l'hystérie et de la mélancolie permet de problématiser une clinique de ces troubles. La tristesse est un dénominateur commun chez ces auteurs. On y additionne les contributions sur l'acédie, le «démon méridien» mentionnée par Agamben. Acédie signifie stagnation, manque désespéré de courage face à une situation pénible et épuisante. L'acédien, qui souffre de façon chronique d'inertie et qui est incapable de dimensionner l'avenir, manifeste une stagnation de la créativité révélée par un isolement douloureux causé par ce qu'on peut appeler la tristesse angoissante - le déni de la tristesse par voie d'action maniaque.
\end{abstract}

Mots clés: Troubles de l'oralité, mélancolie, tristesse, acédie

(Distúrbios de la oralidad en la melancolía: acidia como estagnación)

Este trabajo presenta las valiosas contribuciones de Lasègue, Freud y Abraham,

Rev. Latinoam. Psicopat. Fund., São Paulo, v. 15, n. 3, p. 683-703, setembro 2012 (Suppl.) 
indispensables para la comprensión de los disturbios de la oralidad en la melancolía. Aunque esos autores no utilizan la terminología "disturbios de la oralidad", su comprensión tanto de la histeria como de la melancolía posibilita problematizar una clínica de esos disturbios. La tristeza es un denominador común entre esos autores. Las contribuciones de Agamben sobre la acidia o el "demonio meridiano" se junta a de ellos. Acidia significa estagnación, falta desesperada de ánimo frente a una situación trabajosa y extenuante. El acidioso, aquel que está crónico en su inercia e incapaz de dimensionar el futuro, presenta una estagnación de la creatividad revelada por un aislamiento doloroso provocado por lo que puede ser llamado de tristeza angustiosa - negación de la tristeza por la vía de la acción maniaca.

Palabras claves: Disturbio de la oralidad, melancolía, tristeza, acidia

\section{(Orale Störungen bei Melancholie: Akedia als Stagnation)}

In dieser Studie werden wertvolle Beiträge von Lasegue, Freud und Abraham besprochen, die für das Verständnis der oralen Störungen bei Melancholie unabdingbar sind. Obwohl diese Autoren nicht den Begriff "orale Störungen" verwenden, ermöglicht ihre Auffassung sowohl von Hysterie als auch von Melancholie die Problematisierung einer klinischen Behandlung dieser Störungen. Das Thema Traurigkeit ist ein gemeinsamer Nenner dieser Autoren. Dazu kommen die Beträge zu Akedia, dem “Dämonischen", von dem Agamben spricht. "Akedia” bedeutet Stagnation, verzweifelte Antriebslosigkeit gegenüber einer mühsamen und erschöpfenden Situation. Die "akedische" Person befindet sich in einer chronischen Tatenlosigkeit und ist unfähig, die Zukunft zu ermessen. Diese Person äußert eine Stagnation der durch eine schmerzhafte Isolierung aufgedeckten Kreativität, infolge einer sogenannten verzweifelten Traurigkeit - der Verneinung der Traurigkeit durch ein manisches Handeln.

Schlüsselwörter: Orale Störungen, Melancholie, Traurigkeit, Akedia

Citation/Citação: Magtaz, A.C.; BerLinck, M.T. Orality Disorders in Melancholia: Acedia as Stagnation. Revista Latinoamericana de Psicopatologia Fundamental, São Paulo, v. 15, n. 3, p. 683-703, sept.2012 (Suppl.).

Editor/Editor do artigo: Prof. Dr. Manoel Tosta Berlinck

Received/Recebido: 25.5.2012 / 5.25.2012 Accepted/Aceito: 18.7.2012 / 7.18.2012

Copyright: (C) 2009 University Association for Research in Fundamental Psychopathology / Associação Universitária de Pesquisa em Psicopatologia Fundamental. This is an open-access article, which permits unrestricted use, distribution, and reproduction in any medium, provided the original author and source are credited. / Este é um artigo de livre acesso, que permite uso irrestrito, distribuição e reprodução em qualquer meio, desde que o autor e a fonte sejam citados.

Rev. Latinoam. Psicopat. Fund., São Paulo, v. 15, n. 3, p. 683-703, setembro 2012 (Suppl.) 


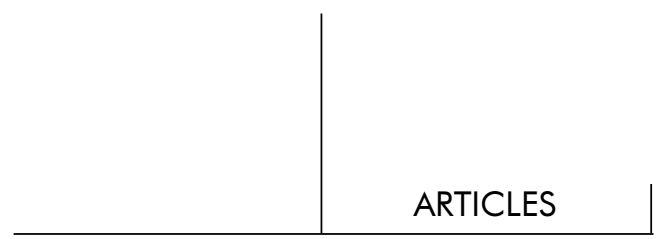

Funding/Financiamento: The authors have no support or funding to report. / Os autores declaram não ter sido financiados ou apoiados.

Conflict of interest/Conflito de interesses: The authors declare that has no conflict of interest. / Os autores declaram que não há conflito de interesses.

\section{Ana Cecília Magtaz}

Psychologist, psychoanalyst, Magtaz earned her doctoral degree from the Graduate Study Program in Clinical Psychology at the Catholic University of São Paulo (PUC-SP/Br.). Professor at the Specialization Course in Psychopathology and Public Health at the University of São Paulo (FSP-USP/Br.), Administrative Director of the University Association for Research in Fundamental Psychopathology - AUPPF, Associated Editor of the Latin American Journal of Fundamental Psychopathology Online.

Rua Monte Alegre, 523/81

05414-000 São Paulo, SP, Br.

Tel.: 55113675.0584

E-mail: acmscaz@uol.com.br

\section{Manoel Tosta BerLinck}

Sociologist, psychoanalyst, Ph.D. (Cornell University, Ithaca, N.Y., USA), Full Professor at the State University of Campinas (1972-1992) (Unicamp) Campinas, SP, Br., Professor at the Graduate Study Program in Clinical Psychology at the Catholic University of São Paulo (PUC$\mathrm{SP} / \mathrm{Br}$.), where he is head of the Laboratory of Fundamental Psychopathology, President of the University Association for Research in Fundamental Psychopathology - AUPPF (2002-2010), Director of Escuta Publishing House (1986-2009), Director of Pulsional Books (1986-2009), editorial consultant and chief-editor of the Latin American Journal of Fundamental Psychopathology, member of the World Association of Medical Editors - WAME (World Association of Medical Editors), author of Psicopatologia Fundamental (2000) and Erotomania with German E. Berrios (2009), among other books and several articles.

Rua Tupi, $397-10^{\circ}$ andar - sala 103

01233-001 São Paulo, SP, Br

Telefax: 55113825.8573

E-mail: mtberlin@uol.com.br

Rev. Latinoam. Psicopat. Fund., São Paulo, v. 15, n. 3, p. 683-703, setembro 2012 (Suppl.) 